\title{
(Ре)конструирование смыслов политической акции в социальной сети «ВКонтакте»: кейс Ивана Голунова ${ }^{1,2}$
}

\author{
А.В. ЩЕКОТУРОВ*, М.И. КРИШТАЛЬ**
}

\begin{abstract}
*Александр Вячеславович Щекотуров - кандидат социологических наук, заведующий социологической лабораторией анализа, моделирования и прогнозирования рисков, Институт гуманитарных наук, Балтийский федеральный университет им. И. Канта. Адрес: 236022, Калининград, ул. Чернышевского, д. 56a. E-mail: ASHCHekoturov@kantiana.ru **Михаил Игоревич Кришталь - кандидат географических наук, научный сотрудник социологической лаборатории анализа, моделирования и прогнозирования рисков, Институт гуманитарных наук, Балтийский федеральный университет им. И. Канта. Адрес: 236022, Калининград, ул. Чернышевского, д. 56a. E-mail: MKrishtal@kantiana.ru

Цитирование: Щекотуров А.В., Кришталь М.И. (2020) (Ре)конструирование смыслов политической акции в социальной сети «ВКонтакте»: кейс Ивана Голунова // Мир России. Т. 29. № 4. С. 150-170. DOI: 10.17323/1811-038X-2020-29-4-150-170
\end{abstract}

В статье рассматриваются специфика и механизмы (ре)конструирования смыслов политической акции в социальной сети «ВКонтакте». В качестве кейса была рассмотрена акиия, возникшая по случаю задержания журналиста Ивана Голунова. Методологической основой исследования послужила теория фрейм-анализа. Опираясь на нее, авторы выявили случаи рефрейминга и транспонирования смыслов политической акции. Основным исследовательским методом выступил контент-анализ, реализованный с помощьью программного обеспечения Atlas.ti. Bсе отобраннье посты были закодированы в соответствии с отношением к задержанию журналиста, стадией развития акции, субъектом фрейминга и используемыми в публикачии хештегами. При кодировке хештегов использовалась оригинальная типология, созданная на основе ичелей, которые они призваны достичь. Установлено, что хештеги способствуют информационному наслоению и транспонированию, переключают первоначальный смысл публикации на новые контексты, что могут впоследствии аккумулировать протестные настроения. В рамках проведенного

\footnotetext{
1 Работа выполнена в рамках исследования «Приватное в публичном: культурные особенности управления самопрезентацией студенческой молодежи в социальных медиа (на примере России и США)» при поддержке гранта Президента Российской Федерации № МК-1909.2019.6 в Балтийском федеральном университете им. И. Канта.

2 Статья опубликована в рамках проекта НИУ ВШЭ по поддержке публикаций авторов российских образовательных и научных организаций «Университетское партнерство».
} 
анализа сформулировано два ключевых вывода. Во-первых, с трансформацией стадий конфликта произошла смена восприятия образа главного фигуранта акиии. Если на стадии конфликта И. Голунов рассматривался как ключевой участник события, то с момента разрешения конфликта начинается использование его образа в качестве символа для совокупного недовольства некоторыми институтами политической системы страны. Во-вторых, была обнаружена специфика в типах системы фреймов, конструируемых сообществами и личными аккаунтами в сочиальной сети "ВКонтакте». Публикации в сообществах характеризуются преимущественно нейтральным содержанием и использованием различных типов хештегов. Публикации в личных аккаунтах отличаются выражением поддержки И. Голунову и использованием хештегов, демонстрируюших солидарность с ним. В итоге были сформулированы новые функиии хештегов - закрепление фрейма (характерно для личных аккаунтов) и PR (свойственно сообществам).

Ключевые слова: политическая акция, фрейм-анализ, Голунов, «ВКонтакте», пост, хештег, протест

Данная работа относится к корпусу исследований, посвященных изучению механизмов репрезентации и конструированию идей политической акции в социальных медиа. Нас интересовала не столько сама политическая акция (т. е. не социальный статус ее участников и цели, которые они преследовали), сколько специфика ее интерпретации и роль публичного пространства социальных медиа в конструировании политических дискурсов. Статья призвана ответить на следующие исследовательские вопросы: какими смыслами в социальных медиа наделяется политическая акция на разных этапах ее развития? Каковы механизмы конструирования различных схем интерпретации политической акции? Кто основные участники публичной риторики и какова их роль в (ре)конструировании смыслов политической акции в социальных медиа?

\section{Политические акции и технологии социальных медиа}

Интерес к роли социальных медиа в политических акциях и социальных протестах возник в ответ на «арабскую весну» и движение «Оккупай». Первые работы были посвящены тому, как онлайн-технологии способствуют координации большого количества людей при отсутствии какого-либо единоначалия и централизации принятия решений [Bennett, Segerberg 2012; Faris 2014]. В результате широкое распространение получили термины «сетевая политика» (networked politics) и «сетевое социальное движение» (networked social movements) [Gonzales-Bailon, Wang 2016]. Ряд авторов пришли к выводу, что именно Интернет и социальные медиа сыграли определяющую роль в мобилизации протестующих. Наиболее знаковой фигурой среди авторов из протехнологического лагеря стал М. Кастельс. В своей книге «Сети произвола и надежды» он пишет, что «арабские восстания были спонтанным процессом мобилизации, возникшим в ответ на призыв в Интернете и беспроводных сетях» [Castells 2012, р. 106], а движение «Оккупай» «зародилось в Интернете, обрело форму в Интернете и сохраняет свое существование в Интернете» [Castells 2012, p. 168]. 
Другие авторы подошли к технодетерминизму критичнее и перенесли акцент на социальные факторы, повлиявшие на рост протестных настроений. В частности, К. Факс пишет, что «не Интернет создает общество, а человек, вовлеченный в антагонистические экономические, политические и идеологические структуры общества» [Fuchs 2014, p. 84]. Значимые обстоятельства протестной активности «зависят от контекста, отношения с властью, стратегии и тактики противостояния, а также от целей и потенциальных результатов борьбы» [Fuchs 2014, p. 84].

Развитие социальной активности посредством социальных медиа вывело на новый уровень такой способ формирования протестных настроений, как киберактивизм, определив еще одно направление научных исследований. Эмпирическое подтверждение получила модель развития протестной активности, предложенная мексиканскими исследователями [Sandoval-Almazan, Gil-Garcia 2014]. Их модель состоит из четырех этапов: первый этап - инициирующее событие, происшествие; второй - реакция СМИ; на третьем этапе (вирусное распространение информации) происходит становление онлайн-сообщества, которое уже имеет эффективные каналы коммуникации и собственный язык общения (участников объединяют единые взгляды и желание взаимодействовать, формируется коллективная идентичность); на четвертом этапе (физический ответ) напряжение, накопившееся в социальных медиа, выражается офлайн - в уличных протестах, митингах и демонстрациях. Здесь активисты видят силу собственной организации, что способствует развитию протестных настроений. Исследователи доказывают, что политическое событие создает собственное дискурсивное поле в традиционных и новых СМИ, появляются лидеры мнений, формируются новые коммуникационные сети.

Более современные исследователи сосредоточились на анализе визуальных образов в социальных медиа и их роли в политической мобилизации населения. Анализ публикаций о международном марше в поддержку прав женщин (январь 2017 г.), размещенных в Facebook и Twitter, показал, что юмористический характер фотографий способствовал эмоциональной сопричастности с протестующими и большей вовлеченности в общественно-политические движения [Bore, Graefer, Kilby 2017]. А. Санина, изучив материалы социальных сетей, посвященные президентским выборам в России, протестному движению и ситуации в Крыму, приходит к выводу, что визуализация протестных эмоций и ирония становятся новой формой политического диалога в России. При этом создание и потребление подобного контента в большей степени развивает слактивизм («диванный активизм»), чем реальный активизм [Sanina 2018].

В России публикации о социальных медиа в контексте политических акций стали появляться после событий 2011-2012 гг., когда по стране прошла волна протестов несогласных с результатами выборов депутатов в Государственную Думу и президента РФ. Основные направления исследований касались вопросов, связанных с ролью социальных сетей в консолидации и мобилизации участников протестных акций [Курочкин 2012; Бударина 2014; Ваньке, Ксенофонтова, Тартаковская 2014]. Ряд авторов придерживаются подхода, согласно которому политическая мобилизация посредством социальных сетей представляет собой управляемый политический процесс, поскольку ключевые акторы социальной сети задают выгодный им политический дискурс, нивелируя идею свободного и суверенного волеизъявления граждан [Курочкин 2012; Бударина 2014]. 
Другие исследователи придерживаются точки зрения, согласно которой социальные сети способствуют свободной консолидации граждан, но при этом уточняют, что возможности виртуальных платформ различны. Так, на примере анализа механизмов политической протестной мобилизации движения «За честные выборы» было установлено, что наименьшим координационным ресурсом обладает площадка «Живого Журнала», являющаяся сервисом для широких дискуссий, где ведется «информационная подготовка к действию» [Ваньке, Ксенофонтова, Тартаковская 2014, с. 71]. Наибольшим потенциалом для политической мобилизации располагает Twitter: именно эта платформа способствует координации действий протестующих. Facebook выступает в качестве платформы для самоорганизации несогласных, пространства для «обретения протестным сообществом собственных границ доверия» [Ваньке, Ксенофонтова, Тартаковская 2014, с. 71]. Д.В. Гончаров и В.В. Нечай в исследовании антикоррупционных протестов в 2017 г. пришли к выводу, что Twitter - эффективный инструмент общественно-политической мобилизации, укрепления солидарности и создания условий для коллективных действий [Гончаров, Нечай 2018].

Механизмам переопределения публичной политической акции в виртуальном пространстве посвящена работа исследовательской группы «Мониторинг актуального фольклора» [Архипова и др. 2018]. Авторы встают на позицию фрейм-анализа, чтобы понять, каким образом митинг как событие трансформируется в митинг как сообщение [Архипова и др. 2018, с. 18]. В результате установлено, что публикация фотографий пикета или митинга в социальных медиа, а также организация акции в Интернете (митинг как сообщение) создают не менее значимые социальные последствия с точки зрения распространения информации и реконструкции смысла политического события. Исследователи приходят к выводу, что границы между физическими и виртуальными пространствами постоянно переопределяются, аудитории дифференцируются в зависимости от фрейма, характеризующего протестный ритуал. Однако сам анализ способов конструирования систем фреймов, их трансформации в процессе развития митинга остался за рамками задач исследователей.

Обзор литературы позволил нам сделать следующий вывод: социальные медиа стали эффективной площадкой для конструирования политического протеста. При этом наблюдается отсутствие реального понимания со стороны государства того, как устроен социальный протест в виртуальном пространстве. Иллюстрацией тому является реакция руководства Москвы во время протестных акций в августе 2019 г., когда применялось глушение мобильной связи и ограничение Интернета ${ }^{3}$. Данный факт демонстрирует, что власти рассматривают исключительно технические средства борьбы для предотвращения нарастания протеста. В связи с этим нуждается в уточнении роль публичного пространства социальных медиа в конструировании политических дискурсов.

Следует отметить, что на фоне формирования новой политической арены отсутствует научное знание о специфике конструирования и трансформации смыслов политической акции в социальных медиа. Вопросом остается и взаимосвязь

3 «Общество защиты Интернета»: на акции 3 августа операторы впервые отключили Интернет по указанию властей Москвы (2019) // Новая газета. 6 августа 2019 // https://novayagazeta.ru/news/2019/08/06/154022obschestvo-zaschity-interneta-na-aktsii-3-avgusta-operatory-vpervye-otklyuchili-internet-po-ukazaniyu-vlastey-moskvy 
участников политической акции в процессе создания и распространения схем интерпретации событий: кто, в какой степени и как определяет формирование информационной повестки.

В данной работе предпринимается попытка пролить свет на обозначенные выше вопросы на примере политической акции, развернувшейся в июне 2019 г. вокруг ситуации с задержанием журналиста Ивана Голунова. Не фокусируясь на целях и составе участников этой политической акции, но стремясь ответить на вопрос, что происходило в социальной сети «ВКонтакте» с момента задержания до освобождения И. Голунова, мы поставили задачу описать и объяснить механизмы конструирования интерпретационных схем политической акции, используемых различными типами коммуникантов.

\section{Возможности фрейм-аналитического исследования социальных медиа}

Поскольку нас интересовали нарративно-интерпретативные механизмы смыслообразования политической акции, то в качестве методологической основы исследования была выбрана теория фреймов. В политологии и политической социологии фрейм-анализ представлен тремя традициями - объективистским фрейманализом И. Гофмана, процессуально-ориентированным подходом Д. Шена и М. Райна, динамическим политическим анализом Д. Яноу и М. ван Хульста.

И. Гофман делает акцент на определении ситуации, поскольку для установления эффективного взаимодействия участвующие в нем субъекты всегда задаются вопросом: «Что здесь происходит?» Ответ на этот вопрос выступает условием фреймирования реальности. Причем для И. Гофмана «не имеет значения, ставится этот вопрос явно или возникает по умолчанию» [Гофман 2004, с. 68], для него «фреймы не создаются сознательно» [Яноу, Хульст 2011, с. 90], они развиваются в процесс интеракции и всегда ситуативны, что делает их объективистскими в сравнении с другими подходами. Объективистское понимание фрейма привлекло внимание теоретиков общественных движений, поскольку, по их мнению, «в обстоятельствах конфликта группы стратегически меняют свои «определения ситуации», чтобы расширить возможности альянсов и коалиций» [Яноу, Хульст 2011, с. 90].

Подход Д. Шена и М. Райна переносит фокус с объекта на процесс фреймирования [Schon, Rein 1994]. В их понимании фрейм - это повествование, определяющее смысл ситуации и характер поведения участников взаимодействия [Schon, Rein 1996, р. 89]. Исследователи подчеркивают, что их «фреймы повествования являются общей сюжетной линией, которая лежит в основе проблематизации события при любых трудноразрешимых политических разногласиях» [Schon, Rein 1996, p. 89].

Д. Яноу и М. ван Хульст отмечают, что их цель - «усилить акцент на процессуальном характере фреймирования» [Яноу, Хульст 2011, с. 89]. Они считают недостаточным когнитивный механизм, предложенный Д. Шеном и М. Райном для фреймирования ситуации, и предлагают динамическую версию фрейм-анализа, основанную на взаимосвязи всех компонентов, помещаемых во фрейм. К таким 
компонентам они относят: 1) конкретные общественные проблемы; 2) идентичности авторов историй и их отношений; 3) сам процесс их взаимодействия [Яноу, Хульст 2011, с. 101].

Согласно логике нашего исследования, наиболее подходящим концептуальным аппаратом для выявления способов наделения события новыми смыслами и их последующей интерпретацией является теория фреймов, представленная в труде И. Гофмана «Анализ фреймов: эссе об организации повседневного опыта» [Гофман 2004] и получившая прикладное развитие в работе В.С. Вахштайна «Социология повседневности и теория фреймов» [Вахштайн 2011]. Преимущество данного подхода заключается в переводе вектора внимания на определение ситуации, что является центральным критерием в анализе (ре)конструирования смыслов с позиции различных политических субъектов на разных этапах политической акции. В данном разделе мы намерены адаптировать теорию фреймов И. Гофмана к исследованию заявленной темы.

Фрейм - экспликация дискретности повседневной жизни. Противопоставляя дискретность поточности, теория фреймов наделяет исследуемую повседневность свойствами «элементарности», «собранности» и «прерывности» [Bахштайн , с. 46]. Экстраполируя данные особенности фрейма на пространство социальных сетей, мы фиксируем, что виртуальная публичная коммуникация также может быть представлена дискретными единицами - постами как единичными высказываниями, при этом каждый пост проблематизирует свой контекст события.

Важной особенностью повседневности, рассматриваемой через оптику фрейм-анализа, является феномен мультипликации, т. е. наслоения социальных контекстов или формирования метаконтекстов. Эффект мультипликации социальных контекстов можно обнаружить и в социальных медиа: хештег как многофункциональный инструмент виртуальной коммуникации [Патрушева 2018] объединяет различные контексты, описываемые в постах пользователей, формируя общее для участников публичной коммуникации информационное поле, или метаконтекст. Созданный с помощью хештегов метаконтекст позволяет эффективнее ориентироваться во множестве смыслов, конструируемых в социальных медиа: пользователю достаточно взглянуть на хештег, чтобы понять, каким содержанием объединены посты в один глобальный коммуникативный поток. Помимо функции мультипликации хештег дополняет смысл публикации, являясь своего рода новым типом «сообщения о сообщении».

Большое значение имеет знакомство с такими понятиями фрейманалитического исследования, как первичные системы фреймов, рефрейминг и переключаемость. Согласно И. Гофману, первичная система фреймов - это базовая, «настоящая» интерпретация события, «нечто осмысленное в тех особенностях сцены, которые в ином случае не имели бы никакого смысла» [Гофман 2004, с. 81].

Рассматривая ситуацию с задержанием И. Голунова, мы выделили три первичные системы фреймов, каждая из которых присутствовала в общем потоке публикаций о деле журналиста: нейтральная (констатирующая оперативно-розыскные мероприятия и не дающая оценок ни действиям полиции, ни словам журналиста), поддерживающая (акцентированная на поддержке И. Голунова и осуждающая действия сотрудников полиции) и критикующая (осуждающая И. Голунова и его сторонников). 
Рефрейминг - новая контекстуализация повседневного сообщения. Другими словами, под рефреймингом понимается ситуация, в которой событие помещается с другой контекст, и «в его распознавании начинает использоваться иная схема» [Вахштайн 2011, с. 59]. В результате рефрейминга событие наделяется новыми смыслами. Примером рефрейминга в социальной сети может стать репост чьейлибо записи, сопровожденный ироническим комментарием с целью изменения смысла передаваемого сообщения.

Под переключением, или транспонированием, И. Гофман понимает процесс трансформирования «определенной деятельности, уже осмысленной в терминах базовой системы фреймов, в иной, с точки зрения участников, вид деятельности» [Гофман 2004, с. 104]. Примером переключения в повседневной жизни, на который ссылается И. Гофман, может быть игра в драку. Базовой системой фреймов здесь служат представления играющих о настоящей драке, но используемые и одинаково понимаемые условности и знаки позволяют участникам выстраивать свое поведение в рамках игры. Транспонирование в социальных медиа проявляется в применении хештегов, позволяющих переносить смысл публикации, понимаемой в одной системе фреймов, в иной метакоммуникативный поток. Однако, в отличие от повседневной жизни, публикации в социальных сетях имеют дело не с деятельностью, а, скорее, с процессом по конструированию и управлению впечатлением. В связи с этим утверждение И. Гофмана, что в результате транспонирования индивид, «улавливая сцепления и взаимодействия событий, приближается к пониманию происходящего» [Гофман 2004, с. 107], в мире виртуальной повседневности будет означать приближение к нужному восприятию происходящего.

На наш взгляд, обнаружение ситуаций рефрейминга и примеров транспонирования представляет собой максимально релевантный исследованию прием для выявления механизмов и интерпретационных схем (ре)конструирования смыслов политической акции в социальных медиа, создаваемых участниками политической акции на разных этапах ее развития.

\section{Методика исследования}

В качестве кейса для анализа (ре)конструирования смыслов политической акции в социальных медиа выбраны ключевые события, развернувшиеся вокруг ареста журналиста-расследователя И. Голунова в июне 2019 г.: его нахождение под стражей, освобождение и проведение массовых акций протеста на следующий день после его выхода на свободу. Выбор этого кейса обусловлен рядом причин. Во-первых, дело оказалось настолько резонансным, что количество упоминаний И. Голунова в социальных медиа обогнало количество упоминаний президента России В.В. Путина (165 тыс. раз против 136 тыс. 8 июня 2019 г.)4. Во-вторых, по этой причине данное событие вскоре охватило иные смысловые контексты -

\footnotetext{
4 Согласно данным Системы мониторинга социальных сетей Brand Analytics (Морозова О. (2019) «Медиалогия»: Голунов опередил Путина по упоминаниям в российских соцмедиа // Сноб. 10 июня 2019 // https://snob.ru/news/178231/).
} 
тему возможного произвола со стороны правоохранительных органов, ограничения деятельности СМИ в России, расследования И. Голунова и т. д.

Единицей анализа выступил пост - публикация, посвященная задержанию И. Голунова. В исследовании была применена сплошная выборка: анализировались все посты в «ВКонтакте», соответствующие хронологическим рамкам и имеющие хештег \#ИванГолунов. Выбор этого хештега обусловлен его нейтральностью, он мог использоваться в постах с различной политической направленностью, эмоциональной окраской и смысловой наполненностью. Выбор социальной сети «ВКонтакте» связан с ее высокой популярностью среди жителей России 5 . Хронологические рамки исследования охватывают период с 9 июня (опубликован первый пост в «ВКонтакте» с хештегом \#ИванГолунов) по 12 июня 2019 г. (день проведения массовых акций протеста по поводу ареста журналиста).

На первом этапе исследования в социальной сети «ВКонтакте» были отобраны публикации, посвященные аресту журналиста $(\mathrm{N}=614)$. На втором этапе проведен контент-анализ публикаций с помощью специализированного программного обеспечения Atlas.ti. Цель контент-анализа заключалась в том, чтобы проследить количественно-качественную связь между стадиями политической акции и 1) отношением к задержанию журналиста; 2) коммуникатором; 3 ) используемыми хештегами. Для обнаружения большего количества механизмов (ре)конструирования смыслов политической акции в социальных медиа дополнительно был проведен корреляционный анализ указанных выше категорий между собой. Метод контент-анализа заключался в присвоении кодов каждой публикации релевантных исследовательской концепции.

Публикации были закодированы в соответствии со следующими принципами. Во-первых, коды присваивались в соответствии с фазами конфликта, в период которых они были созданы:

- фаза «конфликт» (начиная с первого поста 9 июня до первого поста об освобождении Ивана Голунова, $\mathrm{N}=187)$;

- фаза «разрешение конфликта» (начиная с первого поста об освобождении Ивана Голунова до первого поста, информирующего о начале митинга в поддержку Ивана Голунова 12 июня, $\mathrm{N}=212)$;

- фаза «постконфликт» (начиная с первого поста, посвященного митингу в поддержку Ивана Голунова 12 июня, и заканчивая последним постом, опубликованным 12 июня, $\mathrm{N}=215$ ).

Во-вторых, посты были закодированы, исходя из описанного в них отношения к журналисту (первичной системы фреймов): 1) поддерживающие ( $=194)$; 2) нейтральные $(\mathrm{N}=353) ; 3)$ критические $(\mathrm{N}=40)$. Отметим, что еще 27 постов, представляющих собой исключительно набор хештегов, не подвергались данному кодированию.

В-третьих, посты были закодированы в зависимости от того, кто выступал в качестве коммуникатора - группа/сообщество в социальной сети «ВКонтакте» $(\mathrm{N}=325)$ или владелец отдельной страницы $(\mathrm{N}=289)$.

С целью кодирования хештегов была разработана их типология, представленная в таблице 1 .

\footnotetext{
5 Аудитория социальных сетей в России 2019 // $\quad$ Popsters.ru. 18 июня 2019 // https://popsters.ru/blog/post/auditoriya-socsetey-v-rossii
} 


\section{Таблица 1. Типология хештегов}

\begin{tabular}{|c|c|c|c|}
\hline Тип хештегов & Описание хештегов & Примеры хештегов & $\begin{array}{c}\text { Общее } \\
\text { количество }\end{array}$ \\
\hline $\begin{array}{c}\text { Хештег - расширение } \\
\text { контекста }\end{array}$ & $\begin{array}{l}\text { Охватывают новые } \\
\text { смысловые значения }\end{array}$ & $\begin{array}{c}\text { \#Шиес; } \\
\text { \#прямаялиния }\end{array}$ & 227 \\
\hline Хештег-требование & Призывают к чему-либо & $\begin{array}{l}\text { \#СвободуГолунову; } \\
\text { \#засвободуслова }\end{array}$ & 213 \\
\hline Хештег-отклик (за) & В поддержку Ивана Голунова & $\begin{array}{l}\text { \#ЯМыИванГолунов; } \\
\text { \#ЯИванГолунов }\end{array}$ & 188 \\
\hline Хештег-власть & $\begin{array}{c}\text { Упоминание власти } \\
\text { или ее представителей }\end{array}$ & $\begin{array}{c}\text { \#Путин; \#МВД; } \\
\text { \#Кремль; \#Матвиенко }\end{array}$ & 134 \\
\hline Хештег-внимание & $\begin{array}{l}\text { Привлекают внимание к какому-либо } \\
\text { сообществу в социальной сети или СМИ }\end{array}$ & \#Медуза; \#РБК & 122 \\
\hline Хештег-акция & $\begin{array}{c}\text { Обозначают какую-либо } \\
\text { массовую акцию }\end{array}$ & $\begin{array}{l}\text { \#митинг; \#протест; } \\
\text { \#марш }\end{array}$ & 99 \\
\hline Хештег-геопозиция & Обозначают определенную локацию & $\begin{array}{l}\text { \#Москва; \#Россия; } \\
\text { \#КраснаяПлощадь }\end{array}$ & 65 \\
\hline Хештег-контекст & $\begin{array}{l}\text { Передают контекст события, вокруг } \\
\text { которого сгруппированы все посты }\end{array}$ & $\begin{array}{l}\text { \#арест; \#арестГолунова; } \\
\text { \#расследование }\end{array}$ & 65 \\
\hline Хештег-время & $\begin{array}{c}\text { Фиксируют определенный } \\
\text { временной период }\end{array}$ & \#12июня; \#ДеньРоссии & 36 \\
\hline $\begin{array}{l}\text { Хештег - публичные } \\
\text { люди }\end{array}$ & Упоминают общественных деятелей & \#Навальный; \#Соловьев & 36 \\
\hline $\begin{array}{l}\text { Хештег-отклик } \\
\text { (против) }\end{array}$ & $\begin{array}{c}\text { Против Ивана Голунова или высмеивают } \\
\text { ситуацию с его арестом }\end{array}$ & $\begin{array}{c}\text { \#ЯнеИванГолунов; } \\
\text { \#ИванГовнов }\end{array}$ & 6 \\
\hline
\end{tabular}

На третьем этапе были созданы таблицы сопряженности, выполненные в программе Atlas.ti. Они позволили обнаружить наличие или отсутствие связи между кодами (с-коэффициент ${ }^{6}$ ), что в совокупности с качественным анализом текстовых фрагментов позволило обнаружить механизмы (ре)конструирования смыслов, выявить интерпретационные схемы и зафиксировать изменения в системе фреймов в зависимости от этапа развития политической акции.

\section{От Голунова как цели к Голунову как символу: результаты рефрейминга и транспонирования политической акции}

На стадии задержания журналиста доминировали две системы фреймов: нейтральная и поддерживающая (таблица 2). Главная идея публикаций в поддержку журналиста заключалась в том, чтобы выразить свое несогласие с действиями

\footnotetext{
6 Сила сопряженности кодов, обозначаемая в программе Atlas.ti как с-коэффициент, является индикатором силы связи между двумя кодами (Atlas.ti 8 Windows - full manual. 2017. 168 p). Его значения варьируются от 0 (отсутствие связи) до 1 (максимальная сила связи). Показатели с-коэффициента менее 0,1 определялись в исследовании как отсутствие связи.
} 
полиции и склонить большее число читателей к этой точке зрения. Ниже приведем примеры этих публикаций.

«Крепко жму руку каждому Гражданину, выступающему за свободу слова. Солидарность и активность рождает гражданское общество, дорогие» (аккаунт пользователя).

«Иван Голунов - автор ряда расследований о коррупщии в высших эмелонах власти России. За то, что он выводил на чистую воду коррупционеров, сотрудники нашей доблестной полиции ему подкинули “пакетики” и провели обыск с задержанием. Он собирался написать неудобную статью, а значит, правдивую. Такое происходит постоянно, но у многих “обычных” людей нет такого медиаресурса для огласки. Сейчас Ивана отпустили под домашний арест, но это не победа. Победа будет тогда, когда обвинения будут сняты, а те, кто это устроил, понесут наказание. Сейчас он борется за всех нас. Такого единения в поддержку одного человека, одной идеи я давно не припомню. Ивану - свободу! Всем нам любви, надежды и правды» (аккаунт пользователя).

\section{события: \\ Пример публикации, образующей фрейм нейтрального освещения} «Генпрокуратура истребовала дело журналиста Голунова для проверки. Об этом ТАСС сообщил адвокат корреспондента "Медузы” Сергей Бадамиин. Ранее сегодня о деле Голунова омбудсмен Татьяна Москалькова разговаривала с президентом. Она отметила, что необходимо "продолжать контроль со стороны Генпрокуратуры за предварительным следствием - с точки зрения законности и обоснованности”. <..> Иван Голунов находится под домашним арестом по обвинению в покушении на сбыт наркотиков в особо крупном размере. Журналист вину отрицает, утверждая, что запрещенные вещества ему подбросили» (сообщество «Страница новостей»).

Таблица 2. Сила связи различных систем фреймов со стадиями политической акции по делу журналиста И. Голунова

\begin{tabular}{|l|c|c|c|}
\hline Стадия конфликта & Голунов-критика & Голунов-нейтралитет & Голунов-поддержка \\
\hline Конфликт & 0,08 & 0,2 & 0,17 \\
\hline Разрешение конфликта & 0,02 & 0,26 & 0,28 \\
\hline Постконфликт & 0,07 & 0,35 & 0,13 \\
\hline
\end{tabular}

В рамках первого этапа развития акции большую силу связи получили хештеги в поддержку журналиста (таблица 3): хештеги-требования и хештеги-отклики (за), а также хештеги - расширение контекста. 


\title{
Таблица 3. Сила связи типов хештегов со стадиями политической акции по делу журналиста И. Голунова
}

\begin{tabular}{|c|c|c|c|}
\hline Тип хештегов & Конфликт & $\begin{array}{c}\text { Разрешение } \\
\text { конфликта }\end{array}$ & Постконфликт \\
\hline Хештег - расширение контекста & 0,21 & 0,16 & 0,27 \\
\hline Хештег-контекст & 0,05 & 0,12 & 0,09 \\
\hline Хештег-требование & 0,24 & 0,15 & 0,24 \\
\hline Хештег-отклик (за) & 0,2 & 0,16 & 0,22 \\
\hline Хештег-отклик (против) & 0,02 & 0,0 & 0,01 \\
\hline Хештег-власть & 0,09 & 0,14 & 0,2 \\
\hline Хештег-публичные люди & 0,1 & 0,02 & 0,05 \\
\hline Хештег-внимание & 0,16 & 0,17 & 0,12 \\
\hline Хештег-акция & 0,06 & 0,09 & 0,22 \\
\hline Хештег-геопозиция & 0,06 & 0,12 & 0,08 \\
\hline Хештег-время & 0,01 & 0,0 & 0,15 \\
\hline
\end{tabular}

Это свидетельствует о нарастающей экспансии поддерживающего фрейма за счет формирования солидарности несогласных и выдвижения требования о немедленном прекращении уголовного дела. Использование же хештегов, расширяющих контекст события, создало за счет транспонирования смысла политической акции эффект цунами в процессе распространения текстов в поддержку журналиста.

Транспонирование акции иллюстрирует пост, опубликованный в группе «Мы против свалки в Ленском районе»:

\begin{abstract}
«Журналист Иван Голунов - это такой же защитник Шиеса, как и мы!! Статьи Ивана Голунова о мусорной реформе в России были объективными и полезными для всего общества, в том числе он писал и про Шиес. Противозаконные действия в отномении журналиста Ивана Голунова - продолжение беззакония, применяемого органами власти к жстелям Архангельской области, Республики Коми, Московской области и другим регионам. Сегодня продолжается судилище над Анной Шекаловой, дополнительные 5 суток ареста защитнице Шиеса, не совершавщей никаких противоправных действий. < ..> Мы призываем всех ЖУРНАЛИСТОВ продолжить дело Ивана Голунова, добраться 20.06.2019 года до близлежащих поселков, Урдома, Мадмас, станции Шиес, городов Котлас и Коряжма, до столии регионов Сыктывкар или Архангельск, разобраться в сложивщейся ситуации и прорвать стену лжи. Свободу Ивану Голунову! Свободу Анне Шекаловой \#ИванГолунов, \#АннаШекалова, \#Шиес, \#ЗаПравду, \#РукиПрочьОтШиеса».
\end{abstract}

На примере этого поста мы наблюдаем, что вместе с проявлением солидарности в требованиях об освобождении журналиста происходит переключение ситуации на проблему свалок: «Действия в отношении журналиста Ивана Голу- 
нова - продолжение беззакония, применяемого органами власти к жителям Архангельской области». При этом подключаются дополнительные участники фрейма публичные люди (в данном случае эко-активистка А. Шекалова). Использование хештегов с публичными именами свидетельствует о намерении пользователей максимально привлечь внимание к делу И. Голунова и другим проблемам в стране. В тексте мы также видим, как прописными буквами выделено слово «журналист», что придает контексту дополнительный символизм. Этот прием переопределяет журналиста, к которому авторы публикации относят тех, кто поддерживает И. Голунова. Завершается публикация снова переключением события с дела подсудимого на проблему свалок в Республике Коми и Архангельской области.

На стадии разрешения конфликта (освобождение журналиста) наблюдается рост силы корреляции с доминирующими системами фреймов (таблица 2), однако снижается сила связи с хештегами в поддержку И. Голунова (таблица 3) и растет сила корреляции с хештегами -власть и -геопозиция. Это объясняется тем, что: a) ввиду снятия обвинения с И. Голунова отпадает необходимость продолжать требовать его освобождения; б) актуализируется новая протестная повестка обратить внимание властей на другие проблемы в разных регионах страны. В результате анализа публикаций, сделанных 10-11 июня, были выявлены три новых фрейма политической акции: экологические проблемы, митинг 16 июня 2019 г. и политические заключенные. Иллюстрацией каждого нового фрейма могут стать следующие публикации:

\begin{abstract}
Экологические проблемы: «Никто не вспоминает, что в статье, после которой началось сфабрикованное дело Голунова, упоминалось не только про Шиес в Архангельской области, но и про находямуюся совершенно недалеко от нас деревню Михали (Калужская обл.). Рабочих, строящих там мусороперерабатывающий завод и огромный полигон на 1,378 миллионов тонн мусора в год, периодически можно встретить у «Верного» в Уваровке: они приезжают туда закупаться и крайне неохотно рассказьвают про свою работу \#СтопВыброс \#ПодмосковьеНеПомойка \#РоссияНеПомойка \#Подмосковье_нвободуИвануГолунову \#Экология» (сообщество «Храброво: экокатастрофа Можайского г.о.»).

Митинг 16 июня 2019 г.: «Ура! Иван Голунов на свободе! Руководство “Медузы” призывает отказаться от планов проведения мариа 12 июня. Московские власти согласовали его проведение на 16 июня. Митинг в честь освобождения журналиста пройдет на проспекте Сахарова с 13:00 до 15:00 \#москва \#южноебутово \#ясенево \#черемушки» (сообщество «Мой район: Черемушки»).

Политические заключенные: «Уголовное преследование Ивана Голунова прекращено. Это победа? НЕТ! Голунов - один из тысяч человек, которого оправдали, остальные же судимы как «неугодные». Общественность должна добиться пересмотра их дел тоже! Также должны быть привлечены куголовной ответственности люди, фигурировавшие в расследованиях Голунова как коррупиионеры \#Голунов \#ИванГолунов \#РФ \#Россия \#Коррупция \#РепостимГолунова \#вместе \#бытьили_(аккаунт пользователя).
\end{abstract}

Все три новых фрейма стали возможны лишь благодаря существованию первичного фрейма «поддержка Голунова». Таким образом, на этапе разрешения 
конфликтной ситуации наблюдается переключение исходной системы фреймов без смены отношения к задержанию журналиста. Поэтому схема интерпретации события (по мнению несогласных, это нелегитимные действия власти, коррупция, цензура и ограничения в правах) начинает воспроизводиться в иных контекстах: экологических проблемах, митингах и политических заключенных. Каждую новую систему фреймов дополняют релевантные фрейму варианты хештегов.

На стадии постконфликта зафиксировано, что поддержка И. Голунова уступает нейтральному отношению к журналисту, в то время как сила связи с хештегами в его поддержку снова возрастает (таблищь 2 и 3). На этой стадии хештеги - расширение контекста, -власть и -время также получают максимальные значения с-коэффициента $(0,27,0,2$ и 0,15 соответственно). Качественный анализ публикаций выявляет совокупность факторов, объясняющих изменения политической риторики акции.

Во-первых, сохраняется антиправительственный дискурс большинства авторов публикаций. Одобрительный отклик у виртуальной аудитории больше получают посты с требованием наказать настоящих виновников:

«Голунова освободили, но где внутреннее расследование МВД? Следующей хорошей новостью должно стать оглашение имен фальсификаторов и привлечение их к ответственности» (аккаунт пользователя).

«Бандиты срослись с властью и зарабатывают миллиарды на похоронах россиян: там и единороссы, и семьи членов правительства, и силовики. А постоянно растущая смертность населения, вызванная невыносимыми условиями жизни в России, судя по всему, всем им только на руку» (сообщество «Удмуртия против беспредела власти»).

Во-вторых, в период проведения несанкционированного митинга 12 июня в публикациях протестного содержания привлекается внимание властей:

«Сегодня в Москве полииия разогнала мирную акиию против ее же произвола. Произвол многократно повторился. Вдобавок федеральные СМИ вернулись к прежней схеме вещания - не замечать неприятные для власти (читай-Путина) события. Мын настаиваем, чтобы эти вопросы были всей общественностью заданы президенту на "Прямой линии" 20 июня. Чтобы у него не возникло даже намека обойти их стороной, а мерзкие пропагандисты были вынуждены транслировать это на всю страну» (сообщество «PR»).

В-третьих, наблюдаются ситуации рефрейминга: пользователи задают новые интерпретационные рамки проходящей акции протеста против незаконных действий полиции в отношении журналиста:

«С Днем России! 12 июня - это важный и государственный праздник свободы, гражданского мира, согласия и справедливости. "Неадекват” поздравляет Вас и пригла- 
шает за праздничными блюдами, лакомствами и напитками. Добро пожаловать!» (сообщество «Неадекват») или «Как же похоромела Москва при Сергее Семеновиче Собянине! Люди вышли поддержать журналиста, которому по заказу мафии полицейские подбросили наркотики. Мне кажется, это идеальное завершение истории, после которого не остается вопросов» (аккаунт пользователя).

В-четвертых, появляются публикации, в которых фигура И. Голунова представлена уже номинально: он все больше становится символом акции и отношения к власти:

«Сотрудники ОВД “Покровское-Стрешнево” составили на одну из участнии мариа в поддержку журналиста “Медузы” Ивана Голунова административный протокол за то, что она выкрикивала антиправительственный лозунг “Иван Голунов”, привлекая внимание граждан и средств массовой информащии» (аккаунт пользователя). «Какая молодчина Аня Луганская - дочь музыканта, который получал сегодня в Кремле Государственную премию. В течение часа она с первого ряда светила Путину своей майкой с надписью «Я/Мы Иван Голунов» (сообщество «PR»).

На этапе постконфликта также встречаются случаи рефрейминга и транспонирования негативного дискурса в отношении И. Голунова (таблища 2). В пример можно привести цитату из обращения Т. Канделаки к оппозиционерам:

\footnotetext{
«Читаю сводки с марша в поддержку Голунова (однако кого мы обманываем: Голунов лишь повод для этой провокачии). Вас сльишат. С вами говорят. Выже продолжаете принимать всех вокруг за идиотов. Вы презираете общественный интерес, потому что считаете “обществом” только самих себя» (аккаунт пользователя).
}

Фраза, помещенная в скобки, переопределяет событие, отношение к главному фигуранту и, в итоге, к его сторонникам. Автор высказывания пытается применить новую схему интерпретации, согласно которой митингующие стали жертвами заранее подготовленной провокации и информационной манипуляции субъектов, преследующих корыстные интересы.

Таким образом, снижение силы связи с публикациями в поддержку И. Голунова на стадии постконфликта обусловлено ростом вариантов рефрейминга и транспонирования позитивного фрейма. При этом хештеги в защиту журналиста сопровождали все публикации рефрейминга и транспонирования, закрывая схему фрейма тем, что привносили новый смысл - символ протеста и борьбы с цензурой и коррупцией.

Итак, мы можем заключить, что на протяжении трех рассматриваемых этапов развития политической акции фигура И. Голунова меняет свои ипостаси: сначала журналист выступает объектом для приложения усилий по его освобождению, а затем он все более становится символом в борьбе за общегражданские права. 
Благодаря хештегу - расширение контекста происходит транспонирование смысла акции на другие политические арены, умножая первичную схему по недоверию к некоторым институтам власти. Именно в период проведения митинга увеличивается число упоминаний власти не только в тексте публикации, но и в создаваемых хештегах, что усиливает восприятие Голунова в качестве символа протестных настроений.

\section{Закрепление фрейма и PR: результаты исследования публикаций в личных аккаунтах и сообществах}

В таблице 4 видно, что в сообществах преимущественно конституируется нейтральный фрейм (арест журналиста), в то время как в личных аккаунтах чаще наблюдается фрейм поддержки.

Эта специфика может быть обусловлена тем, что пользователь аккаунта обладает большей свободой при выборе фрейма, главным образом выражающего его личное мнение или эмоциональное состояние. Поэтому логичен выбор точки зрения, отражающей собственное отношение к какой-либо тематике. Доминирование нейтрального фрейма в сообществах объясняется тем, что их модераторы стараются не вступать в конфликт со сформировавшимся у подписчиков мнением. Вследствие этого выбор нейтральной позиции является рациональным решением по информированию о событии с сохранением численности подписчиков.

\section{Таблица 4. Корреляция систем фреймов с типом коммуникатора}

\begin{tabular}{|l|c|c|c|}
\hline Тип коммуникатора & Голунов-критика & Голунов-нейтралитет & Голунов-поддержка \\
\hline Сообщество & 0,07 & 0,49 & 0,17 \\
\hline Личный аккаунт & 0,06 & 0,25 & 0,34 \\
\hline
\end{tabular}

Наиболее распространенными типами хештегов при написании постов в личных аккаунтах и сообществах оказались хештеги - расширение контекста, а также хештеги, поддерживающие Ивана Голунова: хештеги-требования и хештеги-отклики (за) (таблица 5). Последние два типа выполняют функцию дополнительного подтверждения фрейма, обозначающего поддержку журналиста. Хештеги, расширяющие контекст, - транспонирование фрейма (например, \#беспредел, \#Шиес, \#сквер и т. д.) с целью демонстрации случаев, в которых, по мнению авторов постов, власти превышали свои полномочия.

Несмотря на то, что указанные типы хештегов чаще всего встречаются и в сообществах, и в личных аккаунтах, между ними есть существенная смысловая разница. Во-первых, на уровне сообществ активно использовались еще хештеги-власть, хештеги-акции и хештеги-внимание (таблица 5). Более высокая корреляция с последним типом обусловлена тем, что он также выполнял функцию PR-сообществ в социальной сети. Специфика применения более широкого спектра 
типов хештегов в сообществах позволяет заключить, что там они используются для создания новых метаконтекстов и информационных потоков, что способствует росту узнаваемости групп и привлечению новых участников.

Во-вторых, сообщества, продвигая нейтральный фрейм (таблица 4), чаще, чем личные аккаунты, используют хештеги в поддержку журналиста (таблица 5). В то же время пользовательские публикации, закрепляя позитивный фрейм, реже, чем сообщества, используют хештег-отклик (за). Объяснением может служить то, что разные коммуникаторы преследуют разные цели: сообщества - быть в тренде и увеличить число подписчиков, личные аккаунты - подкрепить свое отношение, выраженное в тексте, релевантным хештегом. Именно поэтому в публикациях сообществ довольно часто можно встретить хештеги-требования и хештеги-отклики (за) в постах, не посвященных тематике ареста: «Все, ребята. Техника не выдерживает, а мы не “Сноб”, чтоб собрать деньги за день на ее восстановление (да еще, как назло, \$71 млрд госдеповской помощи где-то “Почта России” потеряла). Будем закругляться, возможно, включаясь на особо что-то важное. До завтра \#СМИ \#ЯМыИванГолунов \#ИванГолунов \#СвободуГолунову \#протест \#марш \#МВД \#соцсети» (сообщество PR).

Таблица 5. Различия между сообществом и личным аккаунтом в зависимости от типа используемых хештегов

\begin{tabular}{|l|c|c|}
\hline Тип хештегов & Сообщество & Личный аккаунт \\
\hline Хештег-расширение контекста & 0,29 & 0,24 \\
\hline Хештег-требование & 0,28 & 0,23 \\
\hline Хештег-отклик (за) & 0,29 & 0,17 \\
\hline Хештег-внимание & 0,24 & 0,12 \\
\hline Хештег-власть & 0,26 & 0,08 \\
\hline Хештег-акция & 0,25 & 0,04 \\
\hline Хештег-контекст & 0,14 & 0,06 \\
\hline Хештег-геопозиция & 0,12 & 0,07 \\
\hline Хештег-время & 0,03 & 0,08 \\
\hline Хештег-ппуличные люди & 0,06 & 0,05 \\
\hline Хештег-отклик (против) & 0,01 & 0,01 \\
\hline
\end{tabular}

Таблица 6. Корреляция количества публикаций в сообществах и личных аккаунтах с различными стадиями конфликта

\begin{tabular}{|l|c|c|}
\hline Стадия конфликта & Сообщество & Личный аккаунт \\
\hline Конфликт & 0,22 & 0,23 \\
\hline Разрешение конфликта & 0,25 & 0,26 \\
\hline Постконфликт & 0,29 & 0,23 \\
\hline
\end{tabular}


Сила корреляции типа коммуникатора со стадией конфликта при этом практически не меняется на протяжении всей политической акции (таблица 6).

Таким образом, анализ публикаций в личных аккаунтах и сообществах выявил различия, касающиеся выбора предпочтительного фрейма и типов хештегов. Для постов, опубликованных в сообществах, характерны преобладание нейтрального фрейма и применение более широкого спектра хештегов. В личных аккаунтах, напротив, зафиксированы превалирование фрейма в поддержку Ивана Голунова и довольно узкий набор используемых хештегов. Следовательно, можно выделить две особенности использования хештега: (1) закрепление фрейма = публикация в защиту журналиста + хештеги в его поддержку (характерно для личных аккаунтов); (2) PR-сообщества = публикация нейтрального сообщения + хештеги самых разных типов (характерно для сообществ).

Наряду с этим в постах, опубликованных различными коммуникаторами, наблюдаются и случаи транспонирования фрейма. Это происходит через раскрытие на основе кейса Ивана Голунова иных проблемных ситуаций, связанных с действиями властей. Ключами транспонирования выступают хештеги - расширение контекста (\#беспредел, \#Шиес, \#сквер и т. д.).

\section{Выводы}

В данной статье осмыслена специфика (ре)конструирования политической акции в социальной сети «ВКонтакте» на примере общественной реакции, развернувшейся вокруг ситуации с задержанием журналиста И. Голунова. Исследовательской оптикой выступила теория фрейм-анализа, разработанная в трудах И. Гофмана. Ее применение позволило развить исследование восприятия публичной политической акции в социальных сетях [Архипова и др. 2018]: были проанализированы случаи рефрейминга и транспонирования, что с методологической точки зрения дало возможность доказать релевантность данной теории к изучению виртуального пространства.

Использование программного обеспечения Atlas.ti как инструмента анализа позволило провести контент-анализ сравнительно больших объемов текстовой информации. Возможный субъективный взгляд исследователей в процессе кодирования текста был сведен к минимуму за счет разработки строгой таблицы классификации кодов и совместной работы обоих авторов на всех этапах сбора, обработки и анализа данных.

В результате была разработана оригинальная типология хештегов, используемых при информировании о политической акции в социальной сети. Предложенная типология развивает исследование Л.С. Патрушевой [Патрушева 2018], в котором автор выделяет типы хештегов. Особенностью представленной в данной работе типологии хештегов является обнаружение новых публичных контекстов и акторов, возникающих в процессе метакоммуникативного распространения информации о политической акции. Выявлены новые функции хештегов, изучение которых актуально при исследовании иных политический акций. В частности, выделены хештеги-акторы, репрезентирующие различных участников рассматриваемого кейса (публичных людей, власть, виртуальные сообщества и СМИ); хештеги 
сторонников и противников, выражающие различные позиции в отношении журналиста И. Голунова; митинг-хештеги, раскрывающие подробности протестной акции (ее время и геопозицию), а также хештеги, транслирующие различного рода требования. Установлено, что они способствуют информационному наслоению, транспонированию, переключая первоначальный смысл публикации на новые контексты, что повышает скорость распространения информации и усиливает протестные настроения.

В исследовании выявлена смена восприятия образа главного фигуранта рассматриваемой политической акции. В первые дни после задержания он рассматривался скорее инструментально - как субъект, неправомерно задержанный и потому требующий немедленного освобождения. С момента освобождения И. Голунов обретает, скорее, символический смысл, заключающийся в наделении его образа совокупным недовольством и недоверием к некоторым институтам политической системы страны. Таким образом, пока не решены более глубинные проблемы, первичные системы фреймов могут стать основой для их аккумуляции.

В статье выделены специфики в типах системы фреймов, конструируемых сообществами и пользователями «ВКонтакте». Публикации в сообществах можно характеризовать как преимущественно нейтральные, дополненные множеством типов хештегов, в то время как для публикаций в личных аккаунтах свойственно выражение поддержки И. Голунову и использование хештегов, демонстрирующих солидарность с ним (например, \#ЯМыИванГолунов и \#СвободуГолунову). В результате были сформулированы две дополнительные функции хештегов и, соответственно, новые смыслы, которыми они обогащают публикации: закрепление фрейма (личные аккаунты) и PR (сообщества). Это означает, что последние обладают большим ресурсом для распространения информации и мобилизации пользователей. Публикации в личных аккаунтах, учитывая свойственный им эмоциональный окрас, увеличивают возможность реконструирования исходного значения события, а сами аккаунты потенциально являются источниками усиления протестных настроений. Исходя из этого, можно сделать вывод, что политическая акция тем сильнее, чем больше оппозиционно настроенных пользователей в ключевых сообществах, освещающих эту акцию.

\section{Литература}

Архипова А.С., Радченко Д.А., Титков А.С., Козлова И.В., Югай Е.Ф., Белянин С.В., Гаврилова М.В. (2018) «Пересборка митинга»: Интернет в протесте и протест в интернете // Мониторинг общественного мнения. № 1. С. 12-35. DOI: 10.14515/monitoring.2018.1.02

Бударина К.А. (2014) Сетевые отношения в контексте развития механизмов политической мобилизации // Среднерусский вестник общественных наук. № 5(35). С. 166-168.

Ваньке А.В., Ксенофонтова И.В., Тартаковская И.Н. (2014) Интернет-коммуникация как средство и условие политической мобилизации в России (на примере движения «За честные выборы») // Интеракция. Интервью. Интерпретация. № 7. С. 44-73.

Вахштайн В.С. (2011) Социология повседневности и теория фреймов. СПб.: Издательство Европейского Университета.

Гончаров Д.В., Нечай В.В. (2018) Антикоррупционные протесты 2017: отражение в Твиттере // Полития. № 1(88). C. 65-81. DOI: 10.30570/2078-5089-2018-88-1-65-81 
Гофман И. (2004) Анализ фреймов: Эссе об организации повседневного опыта. М.: Институт социологии РАН.

Курочкин А.В. (2012) Социальные сети как инструмент политической мобилизации: опасность манипуляции и пределы демократии // ПОЛИТЭКС. Т. 8. № 3. С. 200-207.

Патрушева Л.С. (2018) Хештегирование как новый коммуникативный процесс // Вестник Удмуртского университета. Серия: История и Филология. Т. 28. № 3. С. 471-475.

Яноу Д., Хульст М. (2011) Фреймы политического: от фрейм-анализа к анализу фреймирования // Социологическое обозрение. Т. 10. № 1-2. С. 87-113.

Bennett W.L., Segerberg A. (2012) The Logic of Connective Action// Information, Communication and Society, vol. 15, no 5, pp. 739-768. DOI: 10.1080/1369118X.2012.670661

Bore I-L.K., Graefer A., Kilby A. (2017) This Pussy Grabs Back: Humor, Digital Affects and Women's Protests // Open Cultural Studies, vol. 1, no 1, pp. 529-540. DOI: 10.1515/culture-2017-0050

Castells M. (2012) Networks of Outrage and Hope Social Movements in the Internet Age, Chichester, UK: Wiley.

Faris D. (2014) Dissent and Revolution in a Digital Age: Social Media, Blogging and Activism in Egypt // European Journal of Communication, vol. 29, no 3, pp. 392-392. DOI: $10.1177 / 0267323114531873 \mathrm{~g}$

Fuchs C. (2014) Social Media: A Critical Introduction, Sage Publication Ltd. DOI: $10.4135 / 9781446270066$

Gonzales-Bailon S., Wang N. (2016) Networked Discontent: The Anatomy of Protest Campaigns in Social Media // Social Networks, vol. 44,pp. 95-104. DOI: 10.1016/j.socnet.2015.07.003

Sandoval-Almazan R., Gil-Garcia J.R. (2014) Towards Cyberactivism 2.0? Understanding the Use of Social Media and Other Information Technologies for Political Activism and Social Movements // Government Information Quarterly, vol. 31, no 3, pp. 365-378. DOI: $10.1016 /$ j.giq.2013.10.016

Sanina A. (2018) "Who Are You Kidding?": Visual Political Irony in Contemporary Russia // Qualitative Inquiry, vol. 25, no 4, pp. 432-444. DOI: 10.1177/1077800418790292

Schon D., Rein M. (1996) Frame-critical Policy Analysis and Frame-reflective Policy Practice // Knowledge and Policy: The International Journal of Knowledge Transfer and Utilization, vol. 9, no 1, pp. 85-104.

\title{
(Re)constructing the Meanings of a Political Act Using the Social Network VKontakte: the Case of Ivan Golunov?
}

\author{
A. SHCHEKOTUROV*, M. KRISHTAL**
}

\begin{abstract}
*Aleksandr Shchekoturov - PhD in Sociology, Head, Sociological Lab of Analysis, Modeling and Forecasting of Risks, Institute for Humanities, Immanuel Kant Baltic Federal University. Address: 56a, Chernyshevskij St., Kaliningrad, 236022, Russian Federation. E-mail: ASHCHekoturov@kantiana.ru

**Mikhail Krishtal - PhD in Geography, Researcher, Sociological Lab of Analysis, Modeling and Forecasting of Risks, Institute for Humanities, Immanuel Kant Baltic Federal University. Address: 56a, Chernyshevskij St., Kaliningrad, 236022, Russian Federation. E-mail: MKrishtal@kantiana.ru
\end{abstract}

\footnotetext{
7 The work was carried out as part of the study "Private in public: cultural features of student self-presentation management in social media (on example, Russia and the US)" with the support of the grant of President of Russian Federation No. MK-1909.2019.6 at the Immanuel Kant Baltic Federal University.
} 
Citation: Shchekoturov A., Krishtal M. (2020) (Re)constructing the Meanings of a Political Act Using the Social Network VKontakte: the Case of Ivan Golunov. Mir Rossii, vol. 29, no 4, pp. 150-170 (in Russian). DOI: 10.17323/1811-038X-2020-29-4-150-170

\section{Abstract}

This article deals with the specifics and mechanisms of (re)constructing the meanings of political action in the social network VKontakte. In particular, we consider the case of journalist Ivan Golunov's arrest and the political action that followed. Methodologically the study draws on the frame analysis approach, which is used to uncover how the meanings of a political act are reframed and transposed. This method is further enhanced with content analysis implemented in Atlas.ti software. Relevant social media posts were encoded in accordance with the attitude towards the journalist's arrest, the stage of the action, the subject of the framing, and the hashtags used in the publication. An original typology of hashtags was used in the process of encoding. This typology was created on the basis of the goals that the hashtags were designed to achieve. We have established that hashtags contribute to informational layering, transposition and the switching of the initial meaning of publications to new contexts that can subsequently accumulate protest attitudes. We formulate two main conclusions. First, in the course of the conflict the image perception of the key person involved in the action has changed. Whereas at the beginning, Golunov was considered a key participant in the event, from the moment of conflict resolution his image was turned into a symbol of aggregate discontent with the political system and certain institutions. Second, some specifics were revealed in the types of frame systems constructed by communities and individual accounts on the VKontakte social network. Publications in communities are characterized mainly by neutral content and the use of various types of hashtags, whereas publications in individual accounts are distinguished by explicit support for Golunov and the use of hashtags that demonstrate solidarity with him. As a result, new hashtag functions were formulated: frame fixing (typical for individual accounts) and PR (common to communities).

Key words: political action, frame analysis, Golunov, VKontakte, post, hashtag, protest

\section{References}

Arkhipova A.S., Radchenko D.A., Titkov A.S., Kozlova I.V., Yugaj E.F., Belyanin S.V., Gavrilova M.V. (2018) «Peresborka mitinga»: Internet v proteste i protest $\mathrm{v}$ internete ["A Rally Reconfigured": Internet in the Protest and Protest on the Internet]. Monitoring of Public Opinion, no 1, pp. 12-35. DOI: 10.14515/monitoring.2018.1.02

Bennett W.L., Segerberg A. (2012) The Logic of Connective Action. Information, Communication and Society, vol. 15, no 5, pp. 739-768. DOI: 10.1080/1369118X.2012.670661

Bore I-L.K., Graefer A., Kilby A. (2017) This Pussy Grabs Back: Humor, Digital Affects and Women's Protests. Open Cultural Studies, vol. 1, no 1, pp. 529-540. DOI: $10.1515 /$ culture-2017-0050 
Budarina K.A. (2014) Setevye otnosheniya v kontekste razvitiya mekhanizmov politicheskoj mobilizatsii [Network Relations in the Context of the Development of Mechanisms of Political Mobilization]. Central Russian Journal of Social Sciences, no 5(35), pp. 166-168.

Castells M. (2012) Networks of Outrage and Hope Social Movements in the Internet Age, Chichester, UK: Wiley.

Faris D. (2014) Dissent and Revolution in a Digital Age: Social Media, Blogging and Activism in Egypt. European Journal of Communication, vol. 29, no 3, pp. 392-392. DOI: $10.1177 / 0267323114531873 \mathrm{~g}$

Fuchs C. (2014) Social Media: A Critical Introduction, Sage Publication Ltd. DOI: $10.4135 / 9781446270066$

Gofman I. (2004) Analiz frejmov: Esse ob organizatsii povsednevnogo opyta [Frame Analysis: An Essay on Organizing Everyday Experience], Moscow: Institut sotsiologii RAN.

Goncharov D.V., Nechaj V.V. (2018) Antikorruptsionnye protesty 2017: otrazhenie v Tvittere [Anti-corruption Protests 2017: Reflection in Twitter]. Politiya, no 1(88), pp. 65-81.

Gonzales-Bailon S., Wang N. (2016) Networked Discontent: The Anatomy of Protest Campaigns in Social Media. Social Networks, vol. 44, pp. 95-104. DOI: 10.1016/j.socnet.2015.07.003

Kurochkin A.V. (2012) Sotsial'nye seti kak instrument politicheskoj mobilizatsii: opasnost' manipulyatsii i predely demokratii [Social Networks as an Instrument of Political Mobilization: The Danger of Manipulation and the Limits of Democracy]. POLITEX, vol. 8, no 3, pp. 200-207.

Patrusheva L.S. (2018) Kheshtegirovanie kak novyj kommunikativnyj protsess [Hashtagging as a New Communicative Process]. Bulletin of Udmurt University. History and Philology Series, vol. 28, no 3, pp. 471-475.

Sandoval-Almazan R., Gil-Garcia J.R. (2014) Towards Cyberactivism 2.0? Understanding the Use of Social Media and Other Information Technologies for Political Activism and Social Movements. Government Information Quarterly, vol. 31, no 3, pp. 365-378. DOI: $10.1016 /$ j.giq.2013.10.016

Sanina A. (2018) "Who Are You Kidding?": Visual Political Irony in Contemporary Russia. Qualitative Inquiry, vol. 25, no 4, pp. 432-444. DOI: 10.1177/1077800418790292

Schon D., Rein M. (1996) Frame-critical Policy Analysis and Frame-reflective Policy Practice. Knowledge and Policy: The International Journal of Knowledge Transfer and Utilization, vol. 9, no 1, pp. 85-104.

Vakhshtajn V.S. (2011) Sotsiologiya povsednevnosti i teoriya frejmov [Sociology of Everyday Life and the Frame Theory], Saint Petersburg: Izdatel'stvo Evropejskogo Universiteta.

Van'ke A.V., Ksenofontova I.V., Tartakovskaya I.N. (2014) Internet-kommunikatsiya kak sredstvo i uslovie politicheskoj mobilizatsii v Rossii (na primere dvizheniya «Za chestnye vybory») [Internet Communication as a Means and Condition of Political Mobilization in Russia (for Example, the Movement "For Fair Elections"]. Interaction. Interview. Interpretation, no 7, pp. 44-73.

Yanow D., Van Hulst M. (2011) Frejmy politicheskogo: ot frejm-analiza k analizu frejmirovaniya [The Framing of the Political: From Frame-Analysis to the Analysis of Framing]. Sociological Review, vol. 10, no 1-2, pp. 87-113. 